\title{
ANALISIS KUALITAS AIR DAN DAYA TAMPUNG BEBAN PENCEMARAN SUNGAI PESANGGRAHAN DI WILAYAH PROVINSI DKI JAKARTA
}

\author{
Water Quality Analysis and Pollution Load Capacity of Pesanggrahan River, Province of DKI \\ Jakarta
}

\author{
Veybi Djoharamª, Etty Riani ${ }^{\mathrm{b}}$, Mohamad Yanic \\ ${ }^{a}$ Program Studi Ilmu Pengelolaan Daerah Aliran Sungai, Sekolah Pascasarjana, Institut Pertanian Bogor, Kampus \\ IPB Dramaga, Bogor 16680 -veybidj@gmail.com \\ ${ }^{b}$ Departemen Manajemen Sumberdaya Perikanan, Fakultas Perikanan dan Ilmu Kelautan, Institut Pertanian Bogor, \\ Kampus IPB Darmaga, Bogor 16680 \\ ${ }^{c}$ Departemen Teknologi Industri Pertanian, Fakultas Teknologi Pertanian, Institut Pertanian Bogor, Kampus IPB \\ Darmaga, Bogor 16680
}

\begin{abstract}
Pesanggrahan River has important role and function to support human life and ecosystem existing in river area. Daily human activities that utilize river water and then dispose the sewage/waste into Pesanggrahan River can decrease the air quality. This research aims to analyzed the water quality condition of Pesanggrahan River based on physical and chemical water river factors. The analysis was conducted on eight observation points along the Pesanggrahan River in DKI Jakarta Province by testing the air pollution parameters comparing it to the air quality standard of Governmental Regulation No. 82/2001 on Air Quality Management and Air Pollution Control for Class II and Jakarta Governor Regulation No. 582/1995 on the Establishment of the Allocation and Quality Standards of River Water/Raw Water Agency of Liquid Waste Quality Standard in the Special Capital Region of Jakarta for Group C. The parameters observed in this study are 18 and 6 overall physical parameters (temperature and TSS) and parameters chemical ( $p H, D O, B O D$, and COD). Determination of water quality status using pollution index method compared with air quality standard Governmental Regulation No. 82/2001 class II and Jakarta Governor Regulation No. 582/1995 Group $C$. The air quality condition of Pesanggrahan River from upstream to downstream at eight points of observation has generally decreased quality according to parameters of TSS, DO, BOD and COD which were not fulfill the quality standard. Based on the status of water quality status of Pesanggrahan River from upstream to downstream has decreased quality with mild to moderate pollutant status.
\end{abstract}

Keywords: Water pollution, water quality status, water quality, pasanggrahan river

(Diterima: 26-09-2016; Disetujui: 04-04-2017)

\section{Pendahuluan}

Pencemaran dapat terjadi dimana-mana, termasuk di air. Pencemaran pada perairan sebagai dampak dari adanya kegiatan pembangunan dapat juga terjadi pada sumber-sumber air. Terkait hal tersebut maka pencemaran sungai sebagai salah satu sumber air dapat terjadi pada sungai-sungai, terutama yang melintasi kota-kota besar. Contohnya Sungai Ciliwung dari hulu ke hilir dan pencemaran tersebut meningkat secara signifikan di bagian hilir, yakni di wilayah DKI Jakarta (Widhiasari dan Moersidik, 2010). Hal yang sama juga terjadi pada Sungai Cisadane yang mulai dari hulu hingga hilirnya telah tercemar (Siahaan et al., 2011). Selain Sungai Ciliwung dan Sungai Cisadane, sungai yang melintasi kota besar dan diperkirakan telah tercemar di wilayah Jabodetabek adalah Sungai Pesanggrahan.

Sungai Pesanggrahan mengalir dari wilayah Kabupaten Bogor, Kota Depok Provinsi Jawa Barat dan Kota Tangerang Provinsi Banten, hingga masuk ke wilayah Jakarta Selatan, Jakarta Barat dan Jakarta Utara di Provinsi DKI Jakarta. Sungai ini melewati Kecamatan Tanah Sereal, Kecamatan Bojong Gede, Kecamatan Sawangan, Kecamatan Limo, Kecamatan Kebayoran Lama, Kecamatan Pesanggrahan, Kecamatan Kembangan, Kecamatan Kebun Jeruk, hingga akhirnya ke Cengkareng. Sungai Pesanggrahan merupakan sungai yang strategis dalam peruntukannya sebagaimana diamanatkan dalam Keputusan Gubernur DKI Jakarta No. 582/1995 yakni untuk perikanan dan oleh Pemerintah Kota Tangerang Selatan berencana akan memanfaatkan air dari Sungai Pesanggrahan sebagai bahan baku air minum untuk dikonsumsi. Kegiatan dan lahan yang ada di sepanjang Sungai Pesanggrahan, diantaranya adalah kegiatan permukiman, industri, tanah kosong, ruang terbuka hijau (RTH).

Kegiatan permukiman akan memberikan masukan bahan organik ke sungai. Begitupula halnya dengan 
kegiatan-kegiatan lainnya seperti kegiatan industri yang membuang air limbahnya ke Sungai Pesanggrahan, juga berpotensi dapat menyebabkan makin tingginya kandungan bahan pencemar. Tanah kosong yang berbentuk lahan terbuka juga akan menyebabkan tingginya parameter TSS dalam air, keseluruhan kegiatan tersebut menyebabkan terjadinya penurunan kualitas air Sungai Pesanggrahan. Perubahan kegiatan dan perubahan tataguna lahan di sekitar Sungai Pesanggrahan dari waktu ke waktu cukup signifikan, sehingga diduga akan terjadi perubahan kualitas air secara gradual (dari waktu ke waktu). Data penelitian yang melihat kondisi kualitas air di Sungai Pesanggrahan walaupun sudah cukup banyak namun tidak setiap saat ada atau tidak kontinu, sebagai contoh di wilayah provinsi DKI Jakarta pada tahun 2015 belum ada yang melakukan. Oleh karena itu maka penelitian ini perlu dilakukan dengan tujuan untuk menganalisis kondisi kualitas air dan daya tampung beban pencemaran Sungai Pesanggrahan.

\section{Metode Penelitian}

\subsection{Waktu dan Lokasi Penelitian}

Penelitian ini dilakukan pada bulan April tahun 2015 di 8 (delapan) titik sampling, yang merupakan lokasi pertemuan anak sungai yang masuk ke Sungai Pesanggrahan yang ada di wilayah administrasi Provinsi DKI Jakarta. Analisis laboratorium dilakukan pada 5 parameter fisika dan 13 parameter kimia. Lokasi pengambilan sampel disajikan dalam Gambar 1.

\subsection{Metode Analisis Data}

Kualitas air Sungai Pesanggrahan dianalisis secara deskriptif dengan membandingkan hasil uji laboratorium dengan baku mutu PP. 82/2001 untuk peruntukan kelas II serta Kep.Gub. DKI 582/1995 peruntukan Golongan $\mathrm{C}$ serta analisis penentuan status mutu menggunakan metode Index Pencemaran (IP). Status mutu air merupakan tingkat kondisi mutu air yang menunjukkan kondisi cemar atau kondisi baik pada suatu sumber air dalam waktu tertentu dengan membandingkan dengan baku mutu air yang ditetapkan. Indeks Pencemaran (Pollution Index) digunakan untuk menentukan tingkat pencemaran relatif terhadap parameter kualitas air yang diizinkan (Nemerow, 1974). Indeks Pencemaran ditentukan untuk suatu peruntukan, kemudian dapat dikembangkan untuk beberapa peruntukan bagi seluruh bagian badan air atau sebagian dari suatu sungai.

Pengelolaan kualitas air atas dasar indeks pencemaran ini dapat memberi masukan pada pengambil keputusan agar dapat menilai kualitas badan air untuk suatu peruntukan serta melakukan tindakan untuk memperbaiki kualitas, jika terjadi penurunan kualitas akibat kehadiran senyawa pencemar. Pada model indeks pencemaran digunakan berbagai parameter kualitas air, maka penggunaannya dibutuhkan nilai rata-rata dari keseluruhan nilai $\mathrm{Ci} / \mathrm{Lij}$ sebagai tolok ukur pencemaran, tetapi nilai ini tidak akan bermakna jika salah satu nilai $\mathrm{Ci} / \mathrm{Lij}$ bernilai $>1$. Jadi indeks ini harus mencakup nilai $\mathrm{Ci} / \mathrm{Lij}$ maksimum. Sesuai dengan Keputusan Menteri Lingkungan Hidup No. 115 Tahun 2003 perhitungan indeks pencemaran dilakukan dengan menggunakan Persamaan (1).

$$
P I j=\sqrt{\frac{\left(\frac{C i}{L i j}\right)^{2} M+\left(\frac{C i}{L i j}\right)^{2} R}{2}}
$$

Keterangan :

$\begin{array}{ll}P I & : \begin{array}{l}\text { Indeks pencemaran bagi } \\ \text { peruntukan (j) }\end{array} \\ \text { Lij } & : \text { Konsentrasi parameter kualitas air } \\ & \begin{array}{l}\text { yang dicantumkan dalam baku } \\ \text { mutu peruntukan air }(\mathrm{j})\end{array} \\ & : \text { Konsentrasi parameter kualitas air } \\ C i & \text { hasil pengukuran } \\ (C i j / L i j) \mathrm{M} & : \text { Nilai } \text { Cij/Lij maksimum } \\ (C i j / L i j) \mathrm{R} & : \text { Nilai } C i j / L i j \text { rata-rata }\end{array}$

Metode ini dapat langsung menghubungkan tingkat ketercemaran dengan dapat atau tidaknya sungai dipakai untuk penggunaan tertentu dan dengan nilai parameter-parameter tertentu. Evaluasi terhadap nilai indeks pencemaran ditunjukkan Tabel 1.

Cara perhitungan beban pencemaran didasarkan atas pengukuran debit air sungai dan konsentrasi limbah di sungai berdasarkan persamaan Mitsch dan Goesselink (1993) dalam Lampiran II Peraturan Menteri Negara Lingkungan Hidup Nomor 1 Tahun 2010)):

$B P s=Q s \times \boldsymbol{C s}(\boldsymbol{j}) \times \boldsymbol{f}$

Keterangan :

BPs = Beban pencemaran sungai $(\mathrm{kg} / \mathrm{hr})$

Qs = Debit air sungai $\left(\mathrm{m}^{3} /\right.$ detik $)$

$\mathrm{Cs}(\mathrm{j})=$ Konsentrasi unsur pencemar $\mathrm{j}(\mathrm{mg} / \mathrm{lt})$

$\mathrm{f}=$ faktor konversi $=\frac{1 \mathrm{~kg}}{1.000 .000 \mathrm{mg}} \times \frac{1000 \text { liter }}{1 \mathrm{~m}^{3}} \times \frac{84.600 \text { detik }}{1 \text { hari }}=$ $86,4 \frac{\mathrm{kg} \cdot \mathrm{lt} \cdot \mathrm{detik}}{\mathrm{mg} \cdot \mathrm{m}^{3} \cdot \mathrm{hari}}$

Daya tampung beban pencemaran (DTBP) dapat ditentukan dengan menggunakan persamaan sebagai berikut :

$D T B P=$ beban cemar sesuai baku mutu - beban cemar terukur.....

(Sumber : KLH 2003) 


\section{Hasil dan Pembahasan}

\subsection{Penentuan Status Mutu Air di Sungai Pesanggrahan Wilayah DKI Jakarta}

Hasil pengamatan dari data kualitas air Sungai Pesanggrahan wilayah Provinsi DKI Jakarta memperlihatkan bahwa kualitas air di Sungai Pesanggrahan mengalami perubahan sebagai akibat terjadinya pencemaran air. Hal ini diindikasikan dengan turunnya kualitas air sampai tingkat tertentu yang menyebabkan air tidak dapat berfungsi sesuai peruntukannya.

\subsubsection{Kualitas Air}

Kualitas air Sungai Pesanggrahan dilihat dari parameter fisika dan kimia air mengindikasikan telah terjadi penurunan kualitas. Hal ini terlihat dari beberapa parameter kualitas air yang telah melampaui baku mutu yang dipersyaratkan dalam PP No. 82/2001 kelas II dan Kep.Gub.DKI 582/1995 Gol.C. Data selengkapnya disajikan pada Tabel 2.

\section{a. Suhu}

Suhu mempengaruhi reaksi kimia dan biologi yang terjadi di dalam air (Saksena et al., 2008). Kenaikan suhu air di badan air penerima, saluran air, sungai, danau dan lain sebagainya akan menimbulkan akibat sebagai berikut: 1) Jumlah oksigen terlarut di dalam air menurun; 2) Kecepatan reaksi kimia meningkat; 3) Kehidupan ikan dan hewan air lainnya terganggu (Beveridge, 2004). Peningkatan suhu juga menyebabkan terjadinya peningkatan dekomposisi bahan organik oleh mikroba. Selain itu suhu air sungai merupakan faktor pembatas bagi organisme aquatik (Cech, 2005). Suhu air Sungai Pesanggrahan dari hulu hingga hilir pada titik sampling 1-8 berkisar 24.4-25.2 ${ }^{\circ} \mathrm{C}$ semuanya masih memenuhi baku mutu Kelas II PP 82/2001 dan baku mutu Gol.C dalam Kep.Gub.DKI 582/1995. Namun walaupun masih memenuhi Gol.C peruntukan perikanan dan peternakan, kisaran suhu 24.5 - $25.2{ }^{\circ} \mathrm{C}$ perairan Sungai Pesanggrahan di wilayah penelitian masih kurang optimal untuk budidaya perikanan karena bagi kehidupan ikan diperairan tropis suhu optimal berkisar antara $28-32$ ${ }^{\circ} \mathrm{C}$ (Kordi dan Tancung, 2007).

\section{b. Konsentrasi Ion Hidrogen, $\mathrm{pH}$}

$\mathrm{pH}$ air sungai berkisar 4-9. Nilai $\mathrm{pH}$ menjadi faktor yang penting dalam perairan karena nilai $\mathrm{pH}$ pada air akan menentukan sifat air menjadi bersifat asam atau basa yang akan mempengaruhi kehidupan biologi di dalam air. Perubahan keasaman air, baik ke arah alkali maupun asam, akan sangat mengganggu kehidupan ikan dan hewan air lainnya. Kisaran $\mathrm{pH}$ yang cocok bagi organisme aquatik tidak sama tergantung pada jenis organisme tersebut (Cech, 2005). Effendi (2003) menyatakan bahwa sebagian besar biota akuatik peka terhadap perubahan $\mathrm{pH}$ dan menyukai $\mathrm{pH}$ sekitar 7-7.5. Apabila nilai $\mathrm{pH} 6-6.5$ akan menyebabkan keanekaragaman plankton dan hewan mikrobenthos akan menurun. Ikan yang hidup pada perairan dengan nilai $\mathrm{pH}$ tinggi (alkalin) memiliki kandungan amonia yang lebih tinggi pada tubuhnya dibandingkan dengan ikan yang hidup di perairan netral (Tiwary et al., 2013). Kondisi $\mathrm{pH}$ dapat mempengaruhi tingkat toksisitas suatu senyawa kimia, proses biokimiawi perairan, dan proses metabolisme organisme air. Menurut Kordi dan Tancung (2007) derajat keasaman merupakan faktor yang penting dalam proses pengolahan air untuk perbaikan kualitas air. Sebaran $\mathrm{pH}$ air Sungai Pesanggrahan di titik sampling P1-P8 berkisar 7.3 - 7.5 semuanya masih memenuhi baku mutu Kelas II dan dapat disimpulkan bahwa dari parameter $\mathrm{pH}$ kondisi lingkungan di Sungai Pesanggrahan dalam kondisi layak untuk budidaya ikan dan memenuhi Golongan C Kep.Gub.DKI 582/1995 peruntukan perikanan dan peternakan.

\section{c. Total Suspend Solid, TSS}

Padatan Tersuspensi Total (Total Suspend Solid, $T S S$ ) adalah bahan-bahan tersuspensi (diameter $>1 \mu \mathrm{m}$ ) yang tertahan pada saringan Millipore dengan diameter pori $0.45 \mu \mathrm{m}$. TSS terdiri atas lumpur dan pasir halus serta jasad-jasad renik, yang terutama disebabkan oleh kikisan tanah atau erosi tanah yang terbawa ke badan air. Padatan tersuspensi dikategorikan dalam padatan sulit mengendap, sehingga tidak dapat dihilangkan dengan pengendapan gravitasi konvensional (Suprihatin dan Suparno, 2013). Kecerahan air sungai dipengaruhi oleh banyaknya materi tersuspensi yang ada di dalam air sungai. Materi ini akan mempengaruhi masuknya sinar matahari ke air sungai (Cech, 2005). Nilai kekeruhan pada titik P2 dan P3 masih memenuhi peruntukan kelas II PP 82/2001 namun pada titik P1, P4-P8 memiliki nilai kekeruhan berada di atas 30 NTU (Gambar 2). Oleh karena itu secara umum nilai kekeruhan yang diperoleh dari keenam titik sampling berada dalam kondisi tidak layak untuk kriteria budi daya ikan dan satu titik sampling yakni pada titik P7 tidak memenuhi baku mutu peruntukan Gol. C dalam Kep.Gub. DKI 582/95. Akibat kekeruhan yang tinggi dapat mempengaruhi kehidupan dalam air (Swer dan Singh, 2004) yakni akan mengganggu system pernafasan dan daya lihat biota akuatik serta dapat menghambat penetrasi cahaya ke dalam air (Effendi, 2003).

\section{d. Biochemical Oxygen Demand, BOD dan Chemical Oxygen Demand, COD}

Nilai BOD dan COD air sungai dapat menunjukkan banyaknya pencemar organik yang ada di dalam air sungai. BOD memberikan gambaran seberapa banyak oksigen yang telah digunakan oleh aktivitas mikroba selama kurun waktu yang ditentukan (Alaerts dan Santika, 1984). Semakin besar nilai BOD semakin besar tingkat pencemaran air oleh bahan organik. Kandungan BOD yang rendah mengindikasikan bahwa sungai tersebut bebas dari pencemaran bahan organik (Saksena et al., 2008). BOD tinggi dalam air tidak diinginkan karena akan mengurangi DO (Fatoki et al., 
2001). Berbeda dengan BOD, COD mengindikasikan keseluruhan bahan organik yang mudah maupun yang sulit terurai. Kebutuhan oksigen kimia (COD) adalah ukuran banyaknya oksigen total dalam satuan miligram per liter yang diperlukan dalam proses oksidasi kimia bahan organik dalam limbah. Bahan oksidasi yang digunakan adalah kalium dikromat dan merupakan zat pengoksidasi yang kuat untuk mengoksidasi zat organik secara lengkap dalam suasana asam dengan katalis peraksulfat. Bakteri dapat mengoksidasi zat organik menjadi $\mathrm{CO}_{2}$ dan $\mathrm{H}_{2} \mathrm{O}$ sehingga menghasilkan nilai COD yang lebih tinggi dari BOD untuk air yang sama. Bahan-bahan yang stabil terhadap reaksi biologi dan mikroorganisme dapat ikut teroksidasi dalam uji COD. Adanya hubungan antara BOD dan COD, hal ini didasarkan karena jumlah senyawa kimia yang dapat dioksidasi secara kimiawi lebih besar dibanding dengan oksidasi secara biologis (Alaerts dan Santika, 1984). Kualitas air Sungai Pesanggrahan di wilayah penelitian untuk parameter BOD hanya titik sampling P6 yang memenuhi peruntukan Kelas 2 PP 82/2001, namun semua titik sampling P1-P8 masuk memenuhi peruntukan Gol. C Kep.Gub.DKI 582/1995 (Gambar 3). Nilai untuk parameter COD hanya 1 titik sampling yang tidak sesuai untuk peruntukan Kelas II maupun peruntukan Gol. C yakni pada titik sampling P7 sebesar $31.07 \mathrm{mg} / \mathrm{L}$ (Gambar 4) di halaman 5. Tingginya pemakaian oksigen dalam proses reaksi kimia menunjukan tingginya pencemaran bahan organik yang ada dalam perairan (Senila et al., 2007).

\section{e. Dissolved Oxygen, DO}

Oksigen terlarut (Dissolved Oxygen, DO) adalah jumlah oksigen yang terlarut dalam volume air tertentu pada suatu suhu dan tekanan tertentu. DO dalam air sangat dibutuhkan untuk mendukung kehidupan organisme yang ada di dalamnya (Saksena et al., 2008). Sumber utama DO yaitu fotosintesis (Angelier, 2003) selain itu karakteristik sungai juga mempengaruhi keberadaan DO. Karakteristik sungai yang relatif datar menunjukkan pola aliran yang relatif tenang dan tidak ada turbulensi akan menyebabkan proses reaerasi udara ke dalam air menjadi berkurang sehingga proses difusi oksigen ke dalam air sungaipun menjadi tidak optimal (Harsono, 2010).
Oksigen terlarut (DO) merupakan parameter kualitas air yang penting dalam penentuan kehadiran makhluk hidup dalam air. Umumnya konsentrasi DO di suatu perairan akan bersifat sementara atau musiman dan berfluktuasi dari waktu ke waktu kandungan oksigen akan tertahan lebih lama dalam air yang dingin (Said et al., 2004). Nilai DO air Sungai Pesanggrahan semakin ke hilir semakin menurun dan tidak memenuhi standar nilai DO yang disyaratkan dalam baku mutu kelas II dan Gol.C. Bagian hulu yakni pada titik sampling P1-P3 kandungan DO masih memenuhi peruntukan kelas II dan Gol. C yakni di atas $4 \mathrm{mg} / \mathrm{L}$, pada titik sampling P1 dan P2 kandungan DO tergolong tinggi yakni diatas $6 \mathrm{mg} / \mathrm{L}$ (Gambar 5). Hal ini sangat baik untuk organisme air seperti ikan yang memerlukan oksigen terlarut sekitar $5.8 \mathrm{mg} / \mathrm{L}$ (Palmer, 2001).

\subsubsection{Indeks Pencemaran, IP}

Hasil analisis Indeks Pencemaran (PIj) dengan menggunakan baku mutu Kelas II PP.81/2001, menunjukan bahwa titik sampling P4 mengalami cemar sedang dan titik sampling lainnya mengalami cemar ringan. Lokasi P4 merupakan permukiman padat dan terdapat lahan terbuka. Apabila pada analisis indeks pencemaran $(P I j)$ meggunakan baku mutu Gol. C (Kep.Gub.DKI 582/1995) maka semua titik sampling telah tercemar dengan status mengalami cemar ringan (Tabel 3).

\subsection{Daya Tampung Beban Pencemaran}

Daya tampung beban pencemaran Sungai Pesanggrahan telah terlampaui sehingga harus dilakukan pengurangan beban sebesar 47,298 kg/hari untuk parameter BOD dan parameter TSS sebesar $448,088 \mathrm{~kg} /$ hari. Hal ini berdasarkan hasil analisa dengan menggunakan PP 82/2001 untuk Kelas II. Sementara hasil analisa dengan menggunakan Kep.Gub.DKI 582/1995 Sungai Pesanggrahan masih memiliki kemampuan untuk menampung beban pencemaran seperti yang tersaji pada Tabel 4 .

Tabel 1. Evaluasi nilai indeks pencemaran

\begin{tabular}{ccc}
\hline No. & Indeks Pencemar & Mutu Perairan \\
\hline 1 & $0 \leq \mathrm{Pij} \leq 1.0$ & Kondisi baik \\
2 & $1.0<\mathrm{Pij} \leq 5.0$ & Cemar ringan \\
3 & $5.0<\mathrm{Pij} \leq 10$ & Cemar sedang \\
4 & $\mathrm{Pij}>10,0$ & Cemar berat \\
\hline
\end{tabular}

Sumber: KepmenLH No. 115 Tahun 2003 


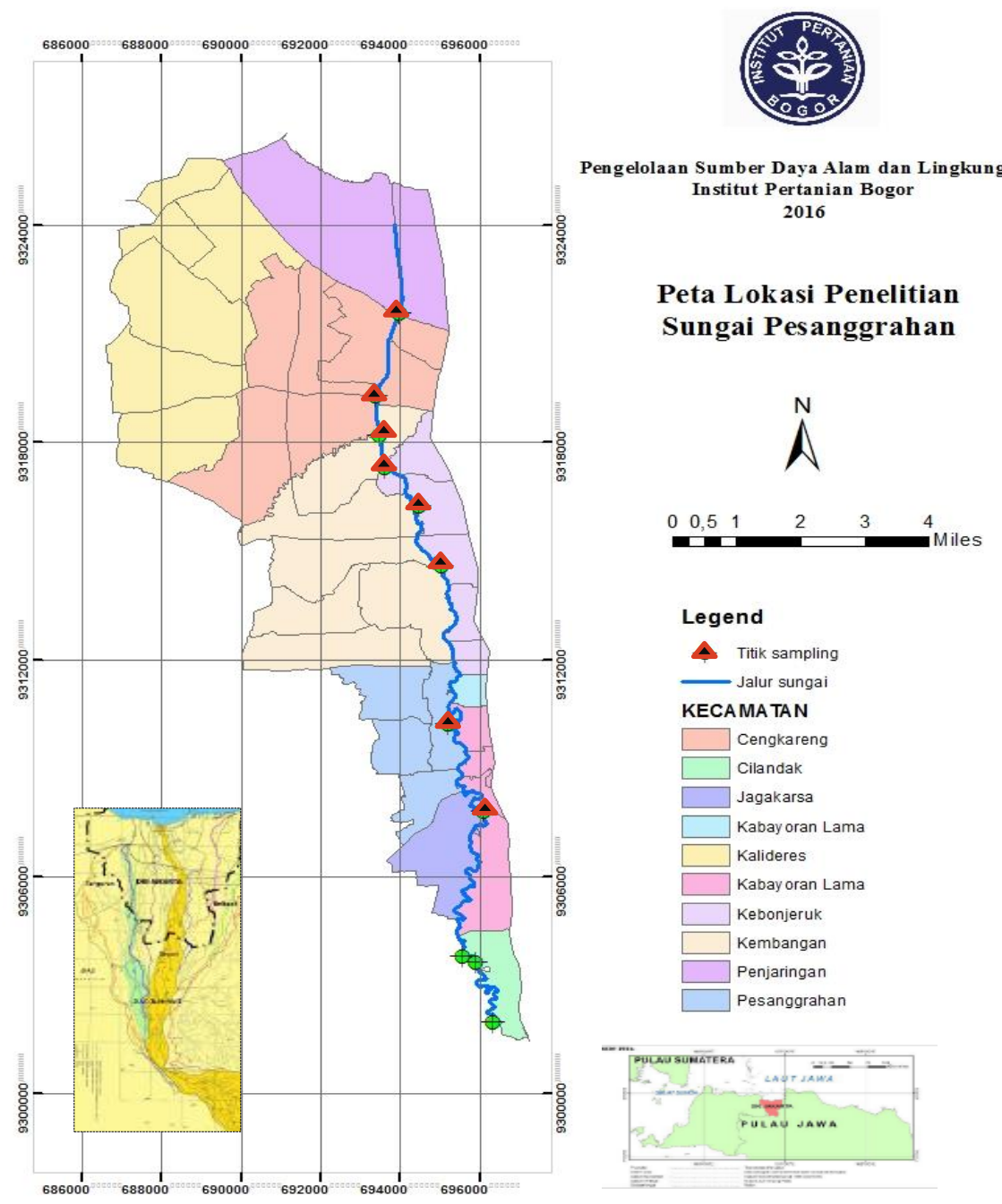

Gambar 1. Peta lokasi penelitian

Tabel 2. Hasil analisis kualitas air Sungai Pesanggrahan bulan April 2015 di delapan titik sampling

\begin{tabular}{|c|c|c|c|c|c|c|c|c|c|c|}
\hline \multirow{2}{*}{ No. } & \multirow{2}{*}{ Parameter } & \multirow{2}{*}{ Satuan } & \multicolumn{8}{|c|}{ Titik sampling } \\
\hline & & & P1 & $\mathrm{P} 2$ & P3 & $\mathrm{P} 4$ & P5 & P6 & P7 & P8 \\
\hline & Fisika & & & & & & & & & \\
\hline 1 & Daya Hantar Listrik (DHL) & $\mu \mathrm{mhos} / \mathrm{cm}$ & 124.8 & 212 & 153.3 & 179 & 176.1 & 170 & 153.6 & 148 \\
\hline 2 & Zat Padat Terlarut (TDS) & $\mathrm{mg} / \mathrm{L}$ & 83.6 & 142 & 102.7 & 120 & 118 & 114 & 102.9 & 99 \\
\hline 3 & $\begin{array}{l}\text { Zat Padat Tersuspensi } \\
\text { (TSS) }\end{array}$ & $\mathrm{mg} / \mathrm{L}$ & 78 & 19 & 40 & 57 & 82 & 59 & 116 & 89 \\
\hline 4 & Suhu & ${ }^{\circ} \mathrm{C}$ & 24.8 & 25.2 & 24.7 & 24.8 & 24.9 & 25.1 & 24.8 & 25 \\
\hline 5 & $\begin{array}{l}\text { Oksigen Terlarut } \\
\text { Kimia }\end{array}$ & $\mathrm{mg} / \mathrm{L}$ & 6.43 & 6.01 & 5.65 & 1.24 & 1.86 & 5.7 & 1.34 & 1.32 \\
\hline 1 & Merkuri (Hg) & $\mathrm{mg} / \mathrm{L}$ & $<0.0003$ & $<0.0003$ & $<0.0003$ & $<0.0003$ & $<0.0003$ & $<0.0003$ & $<0.0003$ & $<0.0003$ \\
\hline 2 & Mangan (Mn) & $\mathrm{mg} / \mathrm{L}$ & $<0.05$ & 0.21 & 0.08 & 0.1 & 0.12 & 0.13 & 0.13 & 0.27 \\
\hline 3 & Nikel (Ni) & $\mathrm{mg} / \mathrm{L}$ & $<0.04$ & $<0.04$ & $<0.04$ & $<0.04$ & $<0.04$ & $<0.04$ & $<0.04$ & $<0.04$ \\
\hline 4 & $\mathrm{pH}$ & - & 7.4 & 7.4 & 7.4 & 7.5 & 7.3 & 7.5 & 7.4 & 7.5 \\
\hline 5 & Total Fosfat & $\mathrm{mg} / \mathrm{L}$ & 0.21 & 0.23 & 0.13 & 0.32 & 0.3 & 0.23 & 0.32 & 0.32 \\
\hline 6 & Seng $(\mathrm{Zn})$ & $\mathrm{mg} / \mathrm{L}$ & 0.12 & 0.13 & 0.22 & 0.06 & 0.08 & 0.08 & 0.06 & 0.29 \\
\hline 7 & Sulfat $\left(\mathrm{SO}_{4}\right)$ & $\mathrm{mg} / \mathrm{L}$ & 10.68 & 15.16 & 7.11 & 30.93 & 17.45 & 25.46 & 7.8 & 20.58 \\
\hline 8 & Tembaga $(\mathrm{Cu})$ & $\mathrm{mg} / \mathrm{L}$ & $<0.02$ & $<0.02$ & $<0.02$ & $<0.02$ & $<0.02$ & $<0.02$ & $<0.02$ & $<0.02$ \\
\hline 9 & Minyak dan Lemak & $\mu \mathrm{g} / \mathrm{L}$ & 150.2 & 95.4 & 270.8 & 161.2 & 142.9 & 197.7 & 219.7 & 150.2 \\
\hline 10 & Senyawa Aktif Biru Metilen & $\mu \mathrm{g} / \mathrm{L}$ & 557 & 101 & 187 & 139 & 115 & 73 & 242 & 112 \\
\hline 11 & Organik $\left(\mathrm{KMnO}_{4}\right)$ & $\mathrm{mg} / \mathrm{L}$ & 10.41 & 10.78 & 7.27 & 14.82 & 11.78 & 4.6 & 23.56 & 14.78 \\
\hline 12 & BOD $\left(20^{\circ} \mathrm{C}, 5\right.$ hari $)$ & $\mathrm{mg} / \mathrm{L}$ & 4.43 & 6.27 & 3.64 & 6.89 & 3.84 & 2.82 & 11.94 & 5.02 \\
\hline 13 & COD (dichromat) & $\mathrm{mg} / \mathrm{L}$ & 12 & 14.1 & 8.5 & 20.5 & 14.5 & 5.9 & 31.07 & 15.2 \\
\hline
\end{tabular}




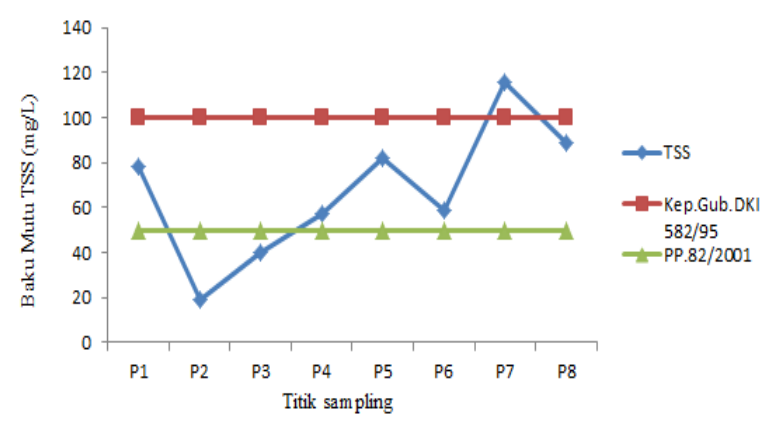

Gambar 2. Nilai TSS air Sungai Pesanggrahan

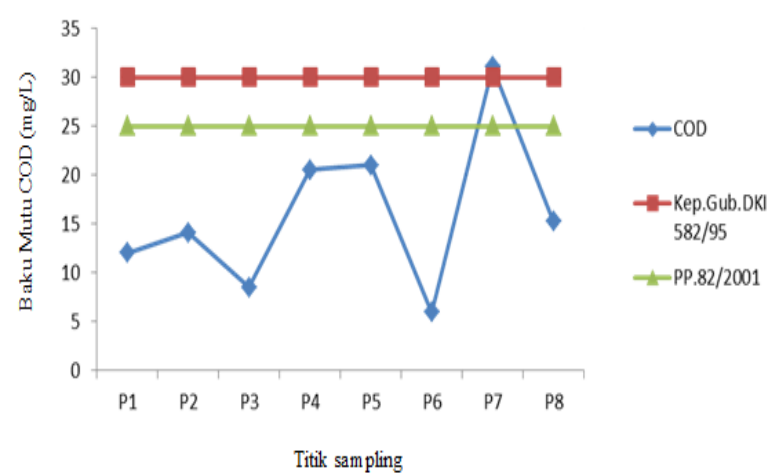

Gambar 4. COD air Sungai Pesanggrahan

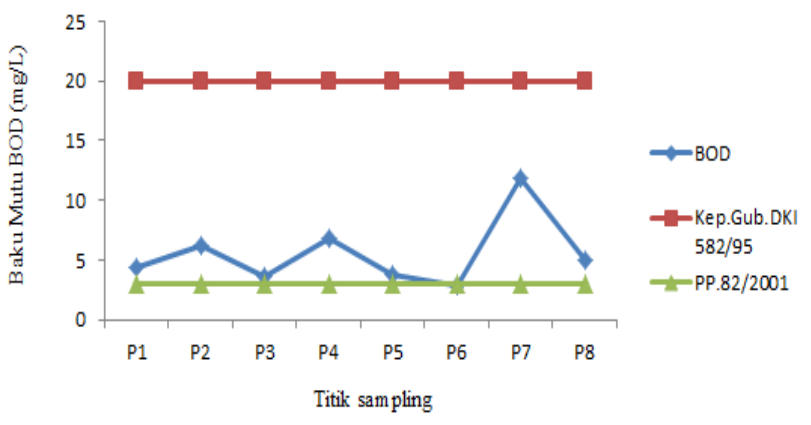

Gambar 3. BOD air sungai Pesanggrahan

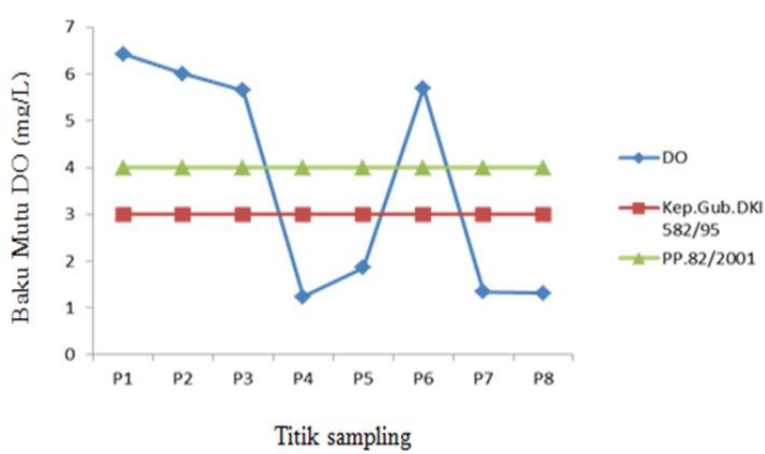

Gambar 5. DO air Sungai Pesanggrahan

\begin{tabular}{|c|c|c|c|c|}
\hline \multirow{2}{*}{$\begin{array}{c}\text { Titik } \\
\text { sampling }\end{array}$} & \multicolumn{2}{|c|}{ Nilai $P I j$} & \multicolumn{2}{|c|}{ Status pencemaran } \\
\hline & $\begin{array}{c}\text { Baku mutu Kelas II } \\
\text { PP 82/2001 }\end{array}$ & $\begin{array}{c}\text { Baku mutu Gol. C } \\
\text { Kep.Gub.DKI } \\
582 / 1995 \\
\end{array}$ & $\begin{array}{c}\text { Baku mutu } \\
\text { Kelas II } \\
\text { PP 82/2001 }\end{array}$ & $\begin{array}{c}\text { Baku mutu Gol. C } \\
\text { Kep.Gub.DKI } \\
582 / 1995\end{array}$ \\
\hline $\mathrm{P} 1$ & 2.5 & 2.1 & Cemar ringan & Cemar ringan \\
\hline $\mathrm{P} 2$ & 2.3 & 2.2 & Cemar ringan & Cemar ringan \\
\hline P3 & 4.9 & 3.1 & Cemar ringan & Cemar ringan \\
\hline $\mathrm{P} 4$ & 6.1 & 3.9 & Cemar sedang & Cemar ringan \\
\hline P5 & 4.2 & 2 & Cemar ringan & Cemar ringan \\
\hline P6 & 1.9 & 1.7 & Cemar ringan & Cemar ringan \\
\hline P7 & 3.1 & 1.1 & Cemar ringan & Cemar ringan \\
\hline P8 & 4.8 & 3.5 & Cemar ringan & Cemar ringan \\
\hline
\end{tabular}

Sumber : Hasil analisis (2015)

Tabel 4. Daya tampung beban pencemaran Sungai Pesanggrahan di lokasi penelitian

\begin{tabular}{|c|c|c|c|c|c|}
\hline \multirow[b]{2}{*}{ Parameter } & \multirow{2}{*}{$\begin{array}{c}\text { Beban } \\
\text { pencemaran } \\
(\mathrm{kg} / \mathrm{hari})\end{array}$} & \multicolumn{2}{|c|}{$\begin{array}{l}\text { Daya tampung } \\
(\mathrm{kg} / \mathrm{hari})\end{array}$} & \multicolumn{2}{|c|}{$\begin{array}{c}\text { Kemampuan menampung } \\
\text { beban pencemaran (kg/hari) }\end{array}$} \\
\hline & & $\begin{array}{c}\text { Baku mutu } \\
\text { Kelas II } \\
\text { PP 82/2001 }\end{array}$ & $\begin{array}{c}\text { Baku mutu Gol. C } \\
\text { Kep.Gub.DKI } \\
582 / 1995\end{array}$ & $\begin{array}{c}\text { Baku mutu } \\
\text { Kelas II } \\
\text { PP 82/2001 }\end{array}$ & $\begin{array}{c}\text { Baku mutu Gol. C } \\
\text { Kep.Gub.DKI } \\
582 / 1995\end{array}$ \\
\hline BOD & 87,915 & 40,617 & 270,778 & $-47,298$ & 182,863 \\
\hline COD & 249,183 & 338,472 & 406,166 & 89,289 & 156,984 \\
\hline TSS & $1,125,032$ & 676,944 & $1,353,888$ & $-448,088$ & 228,856 \\
\hline
\end{tabular}

Sumber : Hasil analisis (2015)

\section{Kesimpulan}

Kualitas air Sungai Pesanggrahan yang melewati wilayah administrasi Provinsi DKI Jakarta dari arah hulu ke hilir telah mengalami penurunan kualitas dengan status tercemar ringan sampai sedang dan 
kemampuan daya tampung beban pencemaran Sungai Pesanggrahan untuk parameter BOD dan TSS telah terlampaui berdasarkan baku mutu dalam PP 82/2001 untuk Kelas II tetapi berdasarkan baku mutu dalam Kep.Gub.DKI 582/1995 untuk Golongan C daya tampung Sungai Pesanggrahan untuk parameter BOD, COD dan TSS belum terlampaui.

\section{Daftar Pustaka}

[1] Alaerts G. dan S. S. Santika, 1984. Metode Pengukuran Kualitas Air. Usaha Nasional, Surabaya.

[2] Angelier E., 2003. Ecology of Streams and Rivers. Science Publishers, Inc., Enfield \& Plymouth.

[3] Beveridge M.C.M., 2004. Cage aquaculture/Malcolm C. M. Beveridge. -3rd ed. Blackwell Publishing Ltd.

[4] Cech T.V., 2005. Principles of Water Resources: History, Development, Management, and Policy. Ed ke-2. Hoboken, John Wiley \& Sons.

[5] Effendi H., 2003. Telaah Kualitas Air Bagi Pengelolaan Sumber Daya Alam dan Lingkungan Perairan. Yogyakarta, Kanisus.

[6] Fatoki O. S., N.Y.O. Muyima, N. Lujiza, 2001. Situation analysis of water quality in Umtata River catchment. Water SA. 27 (4), pp. 467-74.

[7] Harsono E., 2010. Evaluasi Kemampuan Pulih Diri Oksigen Terlarut Air Sungai Citarum Hulu. Jurnal Limnotek. 17(1), pp. 17-36.

[8] Kordi M.G.H.K., A.B. Tancung, 2007. Pengelolaan Kualitas Air Dalam Budi Daya Perairan, Penerbit Rineka Cipta.

[9] Mitsch W., J. Gosselink, 1993. Wetlands. In Water Quality Prevention, Identification and Management of Diffuse Pollution. Van Nostrand Reinhold, New York.

[10] Nemerow N.L., 1974. Industrial Waste Pollution. London, Addison Wesley Publising Company.
[11] Palmer M.D., 2001. Water Quality Modelling Practice: A Guide To Effective. Washington DC, Wold Bank.

[12] Pemerintah Provinsi DKI Jakarta, 1995. Keputusan Gubernur Provinsi DKI Jakarta Nomor 582 Tahun 1995 tentang Penetapan Peruntukan dan Baku Mutu Air Sungai / Badan Air Serta Baku Mutu Limbah Cair di Wilayah Daerah Khusus Ibu Kota Jakarta. Jakarta, Sekretariat Provinsi.

[13] Pemerintah Republik Indonesia, 2001. Peraturan Pemerintah Nomor 82 Tahun 2001 tentang Pengelolaan Kualitas Air dan Pengendalian Pencemaran Air. Jakarta, Sekretariat Negara.

[14] Pemerintah Republik Indonesia, 2003. Keputusan Menteri Negara Lingkungan Hidup Nomor 115 Tahun 2003 tentang Pedoman Penentuan Status Mutu Air. Jakarta, Sekretariat Negara.

[15] Pemerintah Republik Indonesia, 2003. Keputusan Menteri Negara lingkungan Hidup Nomor 110 Tahun 2003 tentang Pedoman Penetapan Daya Tampung Beban Pencemaran Air pada Sumber Air. Jakarta, Sekretariat Negara.

[16] Said A., D. K. Stevens, G. Sehlke. 2004. Environmental assessment an innovative index for evaluating water quality in streams. Environmental Management, 34 (3), pp. 406-14.

[17] Saksena D.N., R.K. Garg, R.J. Rao, 2008. Water quality and pollution status of Chambal River in National Chambal Sanctuary, Madhya Pradesh. Journal of Environmental Biology. 29(5), pp.701-10.

[18] Senila M., E. Levei, M. Miclean, C. Tanaselia, L. David, E. Cordos, 2007. Study regarding the water quality in Aries catchment. Romania, Babes- Bolyai University.

[19] Siahaan R., A. Indrawan, D. Soedharma, B. L. Prasetyo, 2011. Kualitas Air Sungai Cisadane Jawa Barat-Banten. Jurnal Ilmiah Sains. 11(2), pp. 269-273.

[20] Suprihatin, Suparno, 2013. Teknologi Proses Pengolahan Air, Untuk Mahasiswa dan Praktisi Industri. PT Penerbit IPB Press, Bogor.

[21] Swer S., O. P. Singh, 2004. Status of water quality in coal mining areas of Meghalaya, India. Bangladesh, IPHE.

[22] Tiwary C.B., V.S. Pandey, F. Ali, 2013. Effect of $\mathrm{pH}$ on Growth Performance and Survive Rate of Grass Carp. Biolife Journal. 1(4), 172-175.

[23] Widhiasari R., Moersidik, 2010. Daya Tampung DAS Ciliwung [Tesis], Universitas Indonesia. 